\title{
ŠOLA NA OBLAKU: POROČILO O PROJEKTU IN ZAKLJUČNI KONFERENCI
}

Člani Oddelka za geografijo od leta 2013 delujemo v okviru Evropskega projekta vseživljenjskega izobra-

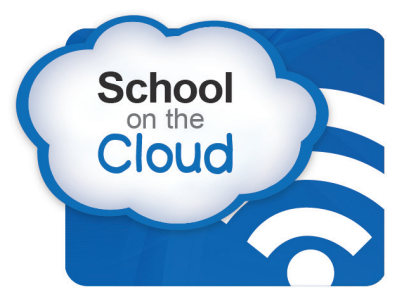
ževanja Šola na oblaku (School on the Coud - SoC, št. projekta 543221-LLP-1-2013-1-GR-KA3-KA3NW), ki se bo zaključil v letu 2017. V projektu se zavzemamo za uvajanje računalništva $\mathrm{v}$ oblaku in drugih sodobnih poti na vseh ravneh izobraževanja. Računalništvo $\mathrm{v}$ oblaku je namreč dodobra spremenilo naš celoten način življenja in dela. $Z$ njegovo pomočjo imamo dostop do digitalnih podatkov (slike, glasba, besedila, prostorski podatki itd.) kjer koli in kadar koli, kjer imamo dostop do svetovnega spleta.

Projekt Šola na oblaku se osredotoča na možnosti, ki jih nudi stalna povezanost in dostopnost za različne oblike izobraževanja in usposabljanja. Računalništvo v oblaku prinaša $v$ izobraževanje izjemno učinkovito ter najsodobnejšo programsko opremo in množico različnih računalniških virov. Pristopi računalništva v oblaku nam omogočajo začrtati nove dinamične načine izobraževanja in učenja, ki so v skladu z načini razmišljanja, deljenja informacij, učenja in sodelovanja znotraj in zunaj učilnice. Delovna orodja omogočajo sodelovanje in motivacijo dijakov in študentov ter tudi usposabljanje različnih družbenih skupin (npr. brezposelnih in vključenih v različna poklicna izobraževanja) za zaposlitev. S projektom smo raziskali, kako naj se izobraževanje na tak razvoj odzove, in sicer z zmanjševanjem obstoječih vrzeli med izobraževanjem in računalništvom v oblaku. Da bi dosegli ta cilj, je projekt Šola na oblaku ustvaril učno mrežo, sestavljeno iz 55 evropskih partnerjev v 18 evropskih državah. Partnerstvo zajema večino izobraževalnih interesnih skupin in vse sektorje izobraževanja. Pri projektu sodelujemo trije člani Oddelka za geografijo (Blaž Repe, Marko Krevs in Tatjana Resnik Planinc). Delo je potekalo v štirih i-delovnih skupinah: i-Vodja, i-Učitelj, i-Učenec in i-Prihodnost.

Prva delovna skupina i-Vodja (i-Manager) je preučevala vidike izobraževalnega vodenja, upravljanja in organizacijske spremembe v obdobju razvoja računalništva v oblaku. Cilj je bil opredeliti in izmenjati tehnološke, socialne, ekonomske, kulturne in druge izkušnje $\mathrm{v}$ različnih izobraževalnih kontekstih. Na podlagi pobude Evropske digitalne agende in Strategije Evropa 2020 je prva delovna skupina obravnavala različne vidike izobraževalnih organizacij, izdelovala smernice za podporo tistim, ki že izvajajo oziroma razmišljajo o razvoju na podlagi računalništva $\mathrm{v}$ oblaku. Ustvarjanje »Zemljevida tehnologij v oblaku« omogoča vsem, ki sodelujejo pri vodenju razvoja računalništva v oblaku, da upoštevajo različne parametre za prenos dobrih praks v svoje okolje.

Druga delovna skupina i-Učitelj (i-Teacher) je preučevala vpliv računalništva $\mathrm{v}$ oblaku na vloge učiteljev in mentorjev v izobraževanju; ugotavljala je, kako lahko nove tehnologije in aplikacije $\mathrm{v}$ oblaku uporabimo, da izobraževanju prinesemo dodano vrednost; obravnavala je težave učenja in poučevanja, povezane $\mathrm{z}$ računalništvom $\mathrm{v}$ oblaku; prepoznavala je na eni strani ključne ovire in na drugi strani vse potrebne kompetence 
učiteljev. Zanimala jih je vloga učitelja kot inovatorja. Delovna skupina je pregledala vse pomembne pristope $\mathrm{k}$ učenju in poučevanju ter podala praktične in bistvene smernice za učitelje in učitelje učiteljev. Med rezultate delovne skupine sodijo: predstavitve vpliva poučevanja in izobraževanja učiteljev, ki temelji na računalništvu v oblaku in vodi k ugotavljanju potreb po usposabljanju učiteljev; spletni katalog priporočenih platform, aplikacij in orodij, ki temeljijo na računalništvu v oblaku; letak z napotki za učitelje in mentorje o poučevanju v oblaku; oblikovanje interaktivne učne delavnice o uporabi računalništva v oblaku za i-Učitelje in i-Mentorje, ki so nosilci aktivnosti in rezultatov same delovne skupine.

Tretja delovna skupina i-Učenec (i-Learner) je $\mathrm{v}$ formalne in neformalne učne situacije povezovala učitelje, mentorje in različne izobraževalne inštitucije (šole, visoke šole in izobraževanje odraslih) z učenjem v oblaku. Delovna skupina je skušala opredeliti posamezniku prilagojeno učenje in nato usmeriti pozornost na tisto, kar tovrstno učenje na podlagi računalništva $\mathrm{v}$ oblaku naredi uspešno. Seznam meril, izdelan na podlagi izvedene raziskave, so uporabili kot okvir za oceno izbranih praktičnih primerov. Izdelali so tudi priročnik, ki pomaga pri ustvarjanju dobro prilagojenega učenja v oblaku. Glavni rezultati te skupine so: vodnik, ki temelji na pregledu najsodobnejše literature z izsledki raziskovalnih in inovativnih projektov; zbirka študij primerov dobrih praks posamezniku prilagojenega učenja, ki učiteljem omogočajo dostop do teh primerov; priročnik za učitelje, koordinatorje in mentorje, ki si ga lahko prenesejo in natisnejo; delavnica za prenos ugotovitev in rezultatov te delovne skupine.

Zadnja, četrta delovna skupina i-Prihodnost (i-Future), je obravnavala tematike, kot so: vloga, procesi in vpliv odprtih (izobraževalnih) virov v oblaku, razpoložljivost brezplačnih in drugih informacij ob uporabi računalništva $\mathrm{v}$ oblaku, nove generacije orodij za uporabo računalništva v oblaku, sporazumevanje in objavljanje v oblaku ter posledične težave (npr. etika in pravice intelektualne lastnine). Te težave se nanašajo tako na organizacije (izobraževalna združenja in združenja učiteljev, nevladne organizacije, založniške organizacije, muzeji, knjižnice, ministrstva) kot tudi na raziskovalce, učitelje, mentorje, upravnike šol, oblikovalce politik in politike. Izsledki delovne skupine so: poročilo o scenarijih za prihodnost, ki so nastali na konferenci projektnih partnerjev; sporočila za javnost o moči, možnostih in šibkostih računalništva v oblaku. Vsi dosedanji izdelki in ugotovitve, katalog spletnih orodij, aplikacij in platform za potrebe učiteljev ipd. so dostopni na spletni strani projekta.

Zaključna konferenca projekta (School on the Cloud: a roadmap to a new teaching and learning paradigm) je bila izvedena 18. novembra 2016 v Bruslju. Le delno je bila namenjena predstavljanju rezultatov in različnih dejavnosti v okviru projekta. Glavni namen je bil ozaveščanje širše strokovne javnosti in politike o že obstoječi »vseprisotnosti« računalništva $\mathrm{v}$ oblaku ter možnostih njegove učinkovite uporabe $\mathrm{v}$ izobraževanju danes in v prihodnje. Prireditev je potekala v flamskem parlamentu. Dodatno težo sta konferenci dala dva zunanja ključna govorca, Sugata Mitra (več o njem na primer Hole in the Wall, 2016; School in the Cloud, 2016; Sugata Mitra, 2016) in Ewan McIntosh (NoTosh, 2016), ki vsak na svojski, a vrhunski način zaznamujeta današnji napredek na področju izobraževanja, podprtega z računalništvom v oblaku. 
V pretežnem delu konference so se odvijale delavnice, na katerih so se udeleženci najprej seznanili z dosežki štirih delovnih skupin v okviru projekta, nato pa s primeri inovativnih orodij, pristopov ter dobrih praks izobraževalne uporabe računalništva $\mathrm{v}$ oblaku. V skladu z značajem projekta in konference je bilo večkrat uporabljenih tudi nekaj spletnih orodij za glasovanje ali bolj kompleksno spletno podprto sodelovanje med udeleženci. Omenjena orodja so bila že preizkušena tudi v nekaterih šolah in so brezplačno dostopna na spletu. Morda bo kateremu od bralcev zanimiv Mentimeter (https:// www.menti.com), namenjen spletno (»oblačno«) podprtemu glasovanju ali zbiranju idej s pomočjo naprav, ki omogočajo dostop do spleta, ali Dotstorming (https://dotstorming. com) in Trello (https://rello.com), namenjena spletno podprti uporabi metod skupinske razprave oziroma možganskega viharja.

Na konferenci so bile izpostavljene tri okoliščine, ki so vsaka na svoj način prispevale k uspešnosti izvedbe projekta. Za kakovost izvedbe projekta, uporabnost ter vplivnost njegovih rezultatov je bilo izrednega pomena sodelovanje raziskovalcev in učiteljev (z najrazličnejših strokovnih področij), učencev, »neizobraževalnih « ustanov, ki so povezane z izobraževanjem (iz Slovenije na primer NUK in Geodetski inštitut Slovenije), »upravljavcev« v izobraževanju (na primer ravnateljev šol, strokovnjakov in odločevalcev z ministrstev za izobraževanje) ter strokovnjakov s področja računalništva v oblaku. Drugo posebnost v primerjavi s podobnimi projekti predstavlja ustanova, ki je vodila projektno delo velike mednarodne mreže tako zelo raznovrstnih ustanov in organizacij. Te funkcije ni opravljala katera od sodelujočih visokošolskih organizacij ali izobraževalnih podjetij, temveč zasebna šola Doukas School iz Aten, ki že udejanja marsikatero zamisel iz projekta. Tretjo pomembno okoliščino je predstavljalo predhodno delovanje velike geografske mreže s področja izobraževalne uporabe informacijsko-komunikacijske tehnologije (člani mreže digitalearth.eu, v tesni zvezi z EUROGEO, tj. Evropsko zvezo geografov; v obeh smo dejavni tudi člani Oddelka za geografijo Filozofske fakultete Univerze v Ljubljani), ki je zasnovala ta projekt ter prispevala velik del partnerjev za njegovo izvedbo.

Številne vznemirljive poglede na prihodnost izobraževanja, ki so bili podani na konferenci, morda najbolje na kratko povzamemo takole. Računalništvo v oblaku omogoča oblike izobraževanja, ki doslej niso obstajale oziroma niso bile mogoče. Mitra se na podlagi lastnih raziskav celo sprašuje, ali lahko »samo-organizirano učno okolje « (SOLE, ang. self-organized learning environment), ki je ena izmed oblik izobraževanja, nadomesti šolo, kakršno poznamo danes. Skupina, ki se je v projektu usmerila v scenarije prihodnosti izobraževanja (v tej skupini je deloval tudi drugi avtor tega zapisa), predvideva vse večjo usmeritev v posamezniku prilagojeno učenje (ang. personalized learning), ki ob temeljiti podpori računalništva v oblaku spreminja paradigmo šolskega izobraževanja (Koutsopoulos, Kotsanis, 2014; Koutsopoulos, Sotiriou, 2015). Težko je bilo spregledati optimistično sporočilo konference, da računalništvo v oblaku prinaša izredno pomembno podporo in okoliščino za modernizacijo vseh ravni izobraževanja in obljubo, da bo projektna mreža v obstoječi ali nekoliko spremenjeni zasedbi nadaljevala s svojim raziskovalnim, didaktičnim in ozaveščevalnim poslanstvom.

Vsi dosedanji izdelki in ugotovitve so na voljo na sledečem spletnem naslovu: http:// www.schoolonthecloud.net/outputs. 
Zanimiv je tudi katalog spletnih orodij, aplikacij in platform za potrebe učiteljev: http://www.schoolonthecloud.net/outputs02.

\section{Literatura in viri}

School on the Cloud. Spletna stran projekta. URL: http://www.schoolonthecloud.net/3rd-summit (10. 12. 2016).

Hole in the Wall Education Project. Spletna stran projekta. URL: http://www.hole-in-the-wall.com/ (10. 12. 2016).

Koutsopoulos, C. K., Kotsanis Y., 2014. School on Cloud: Towards a paradigm shift. Themes in science and technology education, 7, 1, str. 47-62.

Koutsopoulos, K. C., Sotiriou. C.T., 2015. School on the Cloud: A Needed New Paradigm in Open Classroom. IJIRES, 2, 6, str. 511-516.

NoTosh. URL: http://www.notosh.com/ (10. 12. 2016).

School in the Cloud, 2016. URL: https://www.theschoolinthecloud.org/ (10. 12. 2016).

Sugata Mitra. TED. Ideas worth spreading. URL: https://www.ted.com/speakers/sugata_mitra (10. 12. 2016).

Blaž Repe in Marko Krevs 